\title{
Peculiarities of hierarchy of leaders' personal values
}

\author{
Neonila Partyko ${ }^{1}$, Olena Kryvopyshyna ${ }^{2}$, Liubov Pomytkina, ${ }^{3,}$, and Eduard Pomytkin ${ }^{4}$ \\ ${ }^{1}$ Lviv Polytechnic National University, 79013, Bandera Str. 12, Lviv, Ukraine \\ ${ }^{2}$ Lviv State University of Life Safety, Lviv, Ukraine \\ ${ }^{3}$ National Aviation University, 1, ave. Sviatoslav Huzar, 03058, Kyiv, Ukraine \\ ${ }^{4}$ Ivan Ziazun Institute of Pedagogical and Adult Education of the National Academy of Pedagogical \\ Sciences of Ukraine, 9, str. Maxim Berlinsky, 04060, Kyiv, Ukraine
}

\begin{abstract}
The aim of the research is to confirm whether gender, age, residence in rural or urban areas and work experience influence the peculiarities of hierarchy of leaders' personal values, and also to investigate the differences in the hierarchy of leaders' personal values and that of their subordinates. The significant changes in the social value system create for the majority of people the urgent need to adopt new benchmarks and rebuild their personal values system. This also applies directly to the modern leader who is trying to reach a mutual understanding in the relationship. The goal of our research is to study the peculiarities of the hierarchy of leaders' personal values. These were the hypotheses of the study: 1) the specific and individual-oriented values prevail in leaders as well as values of "business" and "self-affirmation"; 2) the hierarchy of value self-determination of modern leaders in education is influenced by their work experience, residence in rural or urban areas, age and gender. To solve the empirical problems of our research and to confirm or refute the hypotheses, we used the method of studying the value orientations, developed by the American researcher Milton Rokeach. According to the results of the research, the most important leaders' terminal values have been the specific and individually oriented values, and the most important leaders' instrumental values have been mainly the values of «business» and «self-affirmation», while gender affects the terminal and instrumental values, and the age impacts mainly instrumental values.
\end{abstract}

\section{Introduction}

Some attempts have been made to describe the properties and components of managers' values by domestic and foreign scientists. Today, the process of the socialisation of youth is complicated by the reassessment of traditions, norms and values. In the production team this is evidenced by various models of self-realisation. For many leaders, the core values are: to find oneself in life, to be humanistic, to achieve material wealth etc.

These attempts are not complete and do not reveal all of the peculiarities of the values. Professional meanings and values occupy the main place in the structure of professional

\footnotetext{
* Corresponding author: Lyubvit@ukr.net
} 
consciousness, as well as hermeneutic, polysemantic, intuitiveness, flexibility, environmental friendliness, existentiality, creativity, dialogue, symbolism.

The main characteristic of the modern leader is not so much the availability of the necessary theoretical knowledge and the formation of techniques and skills. First and foremost, the development of the sense sphere, which includes both professional meanings (personal professional knowledge, the professional attitude to the subordinate, professional ideals, norms and values, meaningful motives of professional activity), as well as developed personal and professional reflection.

The meaning of life can be seen as a value of the highest order. First, it is the professional meaning of life containing the idea of the meaning of the human being, the purpose of man. Second, is the meaning of a professional's life. This aspect relates to the meaning of one's life (family, profession).

An awareness of the meaning of one's own life and the boundary categories of professional activity is thus a necessary component of the professional training of a modern leader. That to which the image the leader is going to respond as a leader, what value orientations he accepts, determines the future of the professional activity itself. Therefore, a detailed study of the valuess of contemporary Ukrainian leaders will allow us to see the core values of leaders in today's transforming society, as well as to identify social and demographic factors that influence the value self-determination of leaders.

The aim of the research is to confirm whether gender, age, residence in rural or urban areas and work experience influence the peculiarities of hierarchy of leaders' personal values, and also to investigate the differences in the hierarchy of leaders' personal values and that of their subordinates. The objectives of our research are the next:

- to analyse the notion of «personal values» and generalise its essence;

- to reveal the impact of different socio-psychological and demographic factors on the hierarchy of leaders' personal values;

- to compare the hierarchy of leaders' personal values and their subordinates' ones.

The methods of our research were theoretical analysis, synthesis, comparison, questionnaire survey (M. Rokeach's technique «Value orientations»); mathematical and statistical methods such as Mann-Whitney U-test, the Kruskal-Wallis test, Pearson's chisquared test $\chi^{2}$.

The American psychologist A. Reber uncovers the term «value» in three meanings. Firstly, value - as a quality or property of an object, which makes it useful and desirable. He draws attention to the pragmatic aspect that is conceived in this definition, meaning that the value of a subject is determined by its role in social interaction, however, in itself there has no value. The second meaning of value A. Reber reveals as an abstract and general principle in relation to behavioral patterns within a particular culture or society. They are social values. They form central principles around which individual and social goals can be integrated Classic examples are freedom, justice, education, etc. The third interpretation of value relates to the sphere of economy. Value is a real worth of an item which is determined by that which can be obtained for it in exchange for either goods or some means of payment, usually money. This meaning is combined with the first one and is very close to the meaning of the term «usefulness» [11, p.169].

Sociologists D. Jerry and J. Jerry define values as ethical ideals and basic beliefs as well as goals of an individual or society. They point out that this term is often used to identify the difference between scientific knowledge and «values», especially, where «ethical» ideals, duty, etc. are not accepted as «scientific» or can become as such [3].

The classification of values is characterised by considerable diversity [11].

In the philosophical and psychological literature it is a description of such hierarchies of the main values as Dionysian, in the center of which is the convenience of life, comfort and consumption; Herculian - domination; Promethean - altruism; the Appolonien - cognition, 
art; Socratic - self-cognition, self-development and self-perfection [11].

H. Schwartz (1992) has developed another influential values theory. The method for determining the values of S. Schwartz's personality was developed by him in accordance with the theoretical construction of universal value types (motivational blocks) - the motivational goals of value orientations and the universality of basic human values [Schwartz, S.H. (1992) Universals in the Content and Structure of Values [18]. Starting from the motivational goal, which determines each type of universal values, Schwartz selected the most characteristic values for each goal.

Thus, the theory of dynamic relations between value types developed by Schwartz describes the conceptual organisation of the value system, according to which the actions performed by an individual in accordance with each type of values have psychological, practical and social consequences. They may be compatible with or conflict with other types of values. The ten value types proposed by Schwartz are organised into two bipolar measurement axes:

- openness to change (values of independence and stimulation) oppose conservatism (values of security, conformity and traditions);

- self-exaltation (values of power and achievements) as opposed to self-transcendence (values of universalism and kindness).

The psychologist S. S. Bubnova distinguishes three hierarchical levels in the system of value orientations of the person. She relates the abstract, most generalised spiritual, social and material values to the first level. Spiritual values, in turn, are differentiated into cognitive, aesthetic, humanistic, and other, social - into the values of social respect, social achievements, social activity, etc. The second level, from the author's point of view, is the values that are fixed in life and manifest as the properties of the person. And the third level is the characteristic ways of person's behaviour as well as means of realisation and consolidation of values-properties [2].

According to Social Learning Theory, the development of achievement motivation depends on the features of socialisation, in particular, on value orientations, as one of the factors [8]. D. McClelland's research using the G. Murray TAT test revealed the individual differences in achievement motivation. And promoting autonomy and personal achievement contribute to faster economic development of the country (McClelland, 2007) [6]. The subject-value level of the person forms the intrinsic motivation for any activity, becomes above the requirements of the situation and transforms it according to the intrinsic values of intrinsic motivation. This is manifested in creativity (Partyko \& Zakalyk, 2019) [8].

The problem of the personal values of the modern leader is urgent, from the point of view of the serious problems of the Ukrainian transforming society. The contemporary researches have not completely covered the issue of personal values of leaders in education in Ukraine in the context of both political and social and economic crises in the country.

From the contemporary Ukrainian sociological literature the most grounded is the definition of value orientations formulated by V. Khmelko [10]. Based on the dispositional concept of V. O. Yadov, value orientations - personal orientations regarding the values of universal, national, class, professional, etc. [14].

\section{Materials and methods}

The personal values of leaders are formed in the process of socialisation during the acquisition of new knowledge and social and psychological experience, manifested in their communication and activities. They are realised in the process of life activity on the basis of individual experience, specific value orientations or acquire personal meaning, or are displaced as not ensuring the successful functioning of the individual in society. 
I. D. Bekh, a well-known modern Ukrainian psychologist, uses the notion of «personal values», which reflects the fact that the subject is included in social relationships and attitudes, and interprets a person as a sociocultural reality [1, p. 95]. More precisely, the notion of «personal values» is associated with the development of particular individuals of social values, and hence, the significance, personal meaning for a person of certain objects, events, phenomena, etc. are fixed after it. The author points out that they act as normalised formations, as prescriptions or prohibitions, which set out a necessary or desired behaviour, or as an ideal, role model. Based on the goals of the psychology of education, I. D. Bekh proposes to understand the personal values of the individual under the conscious values of personality and explains the essence of personal meaning.

M. F. Holovatyi formulates such a definition that value orientations (or rarely preferences) are a certain set of hierarchically connected values which direct life activity [5]. As we can observe, everything comes to the needs of human being, simple usefulness. And here values and value orientations are identified.

Generally, as it was signaled out by M. S. Yanytskyi, theoretical concepts of the second half of the twentieth century, first of all, the domestic tradition, clear up the psychological nature of values through such practically identical notions as "value orientations of the personality" and "personal values" which are differentiated, essentially, only by referring to values more of a motivational or sense bearing sphere.

The changes in society are reflected in some way in the minds of leaders predetermining the changings in their personal values. The factors of leaders' choice of personal values are quite various. They are:

- a social and psychological climate in the production team;

- family environment with its traditions;

- religious beliefs;

- the complex of social and demographic factors.

The changing of values is a rather painful process, the knowing of its patterns and identifying the main factors of the personal values of leaders can help to identify the influence on a modern leader in order to prevent social tensions in today's society.

As a rule, having formed the value picture of the world, the person keeps it constant throughout the life [12]. It is formed mainly at the stage of socialisation of the individual, which precedes the maturity period. In the future, the system of human values changes only in times of crisis [6]. This concerns mostly the structure of values and reflects the changes in priorities, with the result that some values become more meaningful and others give way to them.

In transforming societies this system does not work, as significant changes in the social value system create for the majority of people the urgent need to adopt new benchmarks and rebuild their personal values system. This also applies directly to the modern leader who is trying to reach mutual understanding in relations with subordinates.

The goal of the research is to study the peculiarities of the leaders' personal value hierarchy. There were the hypotheses of the study: 1) the specific and individual-oriented values prevail in leaders as well as values of "business" and "self-affirmation"; 2) the hierarchy of value self-determination of modern leaders in education, is influenced by their work experience, the residence in rural or urban areas, age and gender.

To solve the empirical problems of our research and to confirm or refute the hypotheses, we used the method of studying the value orientations, developed by the American researcher Milton Rokeach. Our study involved 108 people, 40 of whom are managers at different levels in education, and 68 persons - the employees. 38.0\% (41 respondents) residence in the urban area, $62.0 \%$ (67 respondents) - residence in rural areas; among them there are $18.5 \%$ under the age of 35 years (20 respondents), at the age of 35-45 years $43.5 \%$ (47 respondents), at the age of $45-65$ years $-38.0 \%$ (41 respondents); female - 
$41.7 \%$ (45 investigated persons), male - 58.3\% (63 of the investigated persons); with work experience up to 5 years $-20.4 \%$ (22 investigated persons), from 6 to 10 years $-25.0 \%$ (27 investigated persons), more than 10 years $-54.6 \%$ (59 investigated persons).

The Rokeach Value Survey as the main research tool in our research allowed us to study leaders' personal values as the orientation of a person and his attitude to the world around him, to other people, to himself, perception of the world, key motives of actions, the basis of the "philosophy of life".

The creation of this technique is based on the concept of M. Rokeach on the existence of terminal and instrumental values. M. Rokeach divides values and value orientations of the personality into two main groups from the point of view of goals and objectives, which a paricular value serves. It is the psychological approach to the classification of values. The first group consists of «goal values» (terminal values), the second is "means values" (instrumental ones). The terminal values are the main goals of a person, because they reflect the long-term life perspective. Experimental testing of such a division, conducted under the leadership of V. A. Yadov, confirmed its rightness.

It is the terminal values that correlate with the so-called sense-forming motives (D. A. Leontyev), which, from his point of view, are crucial [7]. The value based approach to the study of the peculiarities of the formation of consciousness of the individual, presupposes that all the phenomena of reality (including the actions of people) can be represented as a set of values, which expresses the individuals' subjective assessment of these phenomena from the standpoint of their necessity in meeting their needs and interests.

\section{Results and Discussion}

According to the results of the research, the most important terminal values (TVs) of the leaders were mainly specific and individual-oriented values: active life (fullness and emotional saturation of life), life wisdom (maturity of judgment and common sense, life experience), health (physical and psychic), interesting work, the beauty of nature and art (experiencing the beautiful in nature and in art), love (spiritual and physical intimacy with a loved one).

The least important terminal values of the leaders (TVs) are mostly abstract and oriented to other people - creativity (possibility of creative activity), independence, happiness of others, happy family life, entertainment (pleasant, easy pastime, lack of responsibilities), cognition (the possibility of expanding their education, outlook, general culture, intellectual development).

The most important instrumental values (IV) of the leaders were mainly the values of "affair" and "self-affirmation": education (good manners), irreconcilability to shortcomings, efficiency in affairs (diligence, productivity at work), high demands, responsiveness (care), accuracy (neatness), ability to keep things in order, order in cases.

The least significant instrumental values (IVs) of leaders are ethical and cognitive: responsibility, self-control (restraint, self-discipline), education, independence (ability to act independently, decisively), rationalism (aptitude for deliberate decisions), cheerfulness (sense of humour).

Regarding social and demographic factors of leaders' value self-determination the statistically significant differences in the personal values' self-determination of leaders were revealed depending on their gender, residence status, experience of work and age (see Tables 1-4).

Due to the lack of normal distribution it is the Mann-Whitney U-test we used to compare differences between two independent groups. It has been established by us that for women leaders the following values are more important than for men leaders: life wisdom, 
productive life, courage in defending thought, responsiveness (caring). For male leaders, more important values were development, creativity and tolerance (see Table 1).

Table 1. Differences in value choice of leaders depending on their gender, $N=40$. Source: own research.

\begin{tabular}{|l|c|c|c|c|c|}
\hline \multirow{2}{*}{ Values } & \multicolumn{2}{c|}{$\begin{array}{c}\text { Gender } \\
\text { (rank, median) }\end{array}$} & U-statistic & Z & $\begin{array}{c}\text { Asympt. value } \\
\text { (2-sided) }\end{array}$ \\
\cline { 2 - 5 } & Male & Female & & -1.658 & 0.097 \\
\hline Life wisdom & 1.3 & 6.3 & 69.000 & -2.017 & 0.044 \\
\hline Productive life & 12.5 & 8.0 & 60.500 & -2.576 & 0.010 \\
\hline Development & 5.0 & 11.0 & 47.500 & -1.700 & 0.089 \\
\hline Creativity & 10.5 & 14.7 & 68.500 & -2.082 & 0.037 \\
\hline $\begin{array}{l}\text { Courage in } \\
\text { defending thoughts, } \\
\text { views }\end{array}$ & 14.6 & 8.5 & 59.000 & -2.296 & 0.022 \\
\hline Tolerance & 5.7 & 13.2 & 54.000 & -1.799 & 0.072 \\
\hline Alertness (care) & 10.0 & 6.1 & 68.000 & & \\
\hline
\end{tabular}

For urban leaders the following personal values are more important compared to rural ones: public recognition, parenting (good manners). For rural leaders more important values are freedom, rationalism and efficiency in business (see Table 2).

Using the Kruskal-Wallis test, it has been established that those who have a low (up to 10 years) and high (10+ years) work experience value health (physical and mental) more than the leaders with ten years of experience. Those who have 5 years of work experience compared to the leaders with 10 years of experience are more likely to appreciate the material well-being, happiness of others but they value an interesting job, happy family life, honesty (truthfulness, sincerity) less (see Table 3).

Table 2. Differences in value choice of leaders depending on their living in rural or urban areas, $\mathrm{N}=$ 40. Source: own research.

\begin{tabular}{|l|c|c|c|c|c|}
\hline \multirow{2}{*}{ Values } & \multicolumn{2}{|c|}{$\begin{array}{c}\text { Residence status } \\
\text { (rank, median group) }\end{array}$} & \multirow{2}{*}{ U-statistic } & $\mathbf{Z}$ & $\begin{array}{c}\text { Asympt. value } \\
\text { (2-sided) }\end{array}$ \\
\cline { 2 - 3 } & Urban & Rural & & & 0.096 \\
\hline Public recognition & 9.6 & 11.3 & 62.500 & -1.664 & 0.066 \\
\hline Freedom (good & 14.5 & 9.3 & 58.500 & -1.840 & 0.016 \\
\hline $\begin{array}{l}\text { Parenting } \\
\text { manners) }\end{array}$ & 4.6 & 9.2 & 45.500 & -2.412 & 0.003 \\
\hline Rationalism & 13.3 & 7.3 & 32.500 & -2.980 & 0.036 \\
\hline Efficiency in business & 7.9 & 4.7 & 53.000 & -2.092 & \\
\hline
\end{tabular}


Table 3. Differences in value choice of leaders depending on their experience of work, $\mathrm{N}=40$.

Source: own research.

\begin{tabular}{|l|c|c|c|c|c|c|}
\hline \multirow{2}{*}{ Values } & \multicolumn{4}{|c|}{$\begin{array}{c}\text { Experience of work } \\
\text { (rank, median group) }\end{array}$} & \multicolumn{3}{c|}{ Kruskal-Wallis test } \\
\cline { 2 - 7 } & $\mathbf{5}$ years & $\mathbf{1 0}$ years & $\mathbf{1 0 +}$ years & $\begin{array}{c}\chi^{2} \text {-distribu } \\
\text { tion }\end{array}$ & $\begin{array}{c}\text { degrees of } \\
\text { freedom }\end{array}$ & $\begin{array}{c}\text { Asympt. } \\
\text { value }\end{array}$ \\
\hline $\begin{array}{l}\text { Health (physical } \\
\text { and mental) }\end{array}$ & 7.2 & 5.8 & 11.0 & 5.823 & 2 & 0.054 \\
\hline Interesting job & 12.0 & 9.0 & 3.0 & 6.363 & 2 & 0.042 \\
\hline $\begin{array}{l}\text { Material well- } \\
\text { being }\end{array}$ & 5.7 & 11.2 & 11.3 & 7.393 & 2 & 0.025 \\
\hline Happy family life & 14.7 & 13.3 & 8.5 & 5.255 & 2 & 0.072 \\
\hline $\begin{array}{l}\text { Happiness of } \\
\text { others }\end{array}$ & 4.4 & 14.3 & 14.5 & 8.596 & 2 & 0.014 \\
\hline $\begin{array}{l}\text { Honesty (truth- } \\
\text { fulness, sincerity) }\end{array}$ & 15.0 & 10.0 & 5.0 & 7.089 & 2 & 0.029 \\
\hline
\end{tabular}

By comparing the studied group of executives with the group of subordinates as their TVs and IVs were identified, we found (using the Mann-Whitney U test) that they have been statistically significant for only 4 of the 36 values.

In general «development», «honesty (truthfulness, sincerity)» are more important for the leaders than for their subordinates, and «beauty of nature and art», "accuracy (neatness)», «independence (determination)» are more important for the subordinates.

By the Mann-Whitney U test we compared the studied group of executives with the group of subordinates as far as their TVs and IVCs are displayed in each of the sociodemographic studied subgroups.

Unlike subordinate men, male executives value creativity, tolerance, honesty (truthfulness, sincerity) and value less independence (autonomy, determination). Unlike subordinate women, female executives value more honesty (truthfulness, sincerity) and value less development and independence (determination).

The leaders under 35 years of age, unlike the subordinates of the same age, value the happiness of others more and they appreciate less the beauty of nature and art, happy family life, diligence (discipline). And the leaders at the age of 35-45 years, unlike the subordinates of the same age, value the productive life more and appreciate the responsiveness (care) less.

Table 4. Differences in value choice of leaders depending on their age, $\mathrm{N}=40$. Source: own research.

\begin{tabular}{|l|c|c|c|c|c|c|}
\hline \multirow{2}{*}{ Values } & \multicolumn{3}{|c|}{$\begin{array}{c}\text { Age } \\
\text { (rank, median) }\end{array}$} & \multicolumn{2}{c|}{ Kruskal-Wallis test } \\
\cline { 2 - 7 } & $\begin{array}{c}\text { up to 35 } \\
\text { years old }\end{array}$ & $\begin{array}{c}\text { at the age } \\
\text { of 35-45 } \\
\text { years }\end{array}$ & $\begin{array}{c}\text { at the age } \\
\text { of 45-65 } \\
\text { years }\end{array}$ & $\begin{array}{c}\text { 2-distribu } \\
\text { tion }\end{array}$ & $\begin{array}{c}\text { degrees of } \\
\text { freedom }\end{array}$ & $\begin{array}{c}\text { Asympt. } \\
\text { value }\end{array}$ \\
\hline Interesting job & 16.0 & 4.7 & 8.0 & 7.571 & 2 & 0.023 \\
\hline Happy family life & 15.5 & 15.0 & 9.2 & 5.727 & 2 & 0.057 \\
\hline $\begin{array}{l}\text { Independence } \\
\text { (auto-nomy } \\
\text { resoluteness) }\end{array}$ & 6.3 & 8.0 & 15.3 & 12.531 & 2 & 0.002 \\
\hline $\begin{array}{l}\text { Honesty (truth- } \\
\text { fulness, sincerity) }\end{array}$ & 16.0 & 9.3 & 7.3 & 5.443 & 2 & 0.066 \\
\hline
\end{tabular}


The leaders aged 45-65 years old, unlike the subordinates of the same age, value interesting work, a happy family life, honesty (truthfulness, sincerity) more and value materially secured life, accuracy (neatness), independence (determination), intransigence to disadvantages, rationalism less.

The unmarried executives, compared to unmarried subordinates, value efficiency in cases, firm will, honesty (truthfulness, sincerity) more and value accuracy (neatness), independence (determination), intransigence to disadvantages less. The married executives, compared to married subordinates, value honesty (truthfulness, sincerity) more and value development and independence (determination) less.

The leaders with 5-10 years of experience more than the subordinates with the same experience value health, diligence (discipline), honesty (truthfulness, sincerity) and appreciation less.

The leaders who have more than 10 years of experience, compared to their subordinates with the same experience, value the breadth of views, honesty (truthfulness, sincerity), efficiency in affairs more and appreciate the beauty of nature and art, accuracy (neatness), independence (determination), diligence (discipline) less.

Thus in our research we have found that the educational leaders and the subordinates do not have significant differences in their personal values in modern society.

\section{Conclusion}

We have not found any statistically significant differences in gender, age, work experience and residence status between the sub-groups of «leaders» and «subordinates» (Pearson's chi-squared test $\chi^{2}$ ) in our study. There has been revealed that the value self-determination of leaders in education in the contemporary realities of Ukrainian society is influenced by their work experience and their gender. The age and the residence status of the leaders do not affect their personal values.

According to the results of the research, the most important leaders' terminal values have been the specific and individually oriented values, and the most important leaders' instrumental values are mainly the values of «business» and «self-affirmation», while the work experience impacts mainly instrumental values, and the gender affects the terminal and instrumental values.

\section{References}

1. I.D. Bekh, Vykhovannja osobystosti. Osobystisno orijentovanyj pidkhid: teoretykotekhnologhichni zasady (Lybidj, Kyjiv, 2003)

2. S.S. Bubnova, Psikhologicheskiy zhurnal 5(20), 38-44 (1999)

3. V.V. Gavriliuk, N.A. Trikoz, Sotsiologicheskie issledovaniya 1, 96-105 (2002)

4. G.M. Zakalyk, N.V. Partyko, Psykhologhija innovacij ta reklamy (Vydavnyctvo Ljvivsjkoji politekhniky, Ljviv, 2019)

5. M.F. Holovatyi, Sotsiologiya molodezhi: Kurs lektsi (MAUP, K., 1999)

6. D. McClelland, Motyvacyja cheloveka (Piter, Sankt-Peterburgh, 2007)

7. D.A. Leontyev, Psikhologiya smysla: priroda, stroenie i dinamika smyslovoy real'nosti (Smysl, M., 2003)

8. N.V. Partyko, G.M. Zakalyk, Psykhologhichni osnovy rozvytku osobystosti (Zaporizhzhia, Prosvita, 2019) 
9. M. Rokich, Issledovanie tsennostnykh orientatsiy, http://psycabi.net/testy/320metodika-rokicha-tsennostnye-orientatsii-test-miltona-rokicha-issledovanietsennostnykh-orientatsij-m-rokicha-oprosnik-tsennosti-po-rokichu

10. Sociologhija: korotkyj encyklopedychnyj slovnyk (Ukr. Centr dukhovn. Kuljtury, K., 1998)

11. N.V. Voloshyna, Development Trends in Pedagogical and Psychological Sciences: the Experience of Countries of Eastern Europe and Prospects of Ukraine ("Baltija Publishing", Riga, Latvia, 2018) DOI: http://dx.doi.org/10.30525/978-9934-571-275_8

12. M.S. Yanitskiy, Tsennostnye orientatsii lichnosti kak dinamicheskaya sistema (2010) http://hpsy.ru/public/x2754.htm

13. M.S. Yanitskiy, Nauchnyy vestnik Kemerovskogo gosudarstvennogo universiteta 2(22), 15-18 (2005)

14. V.A. Yadov, $O$ dispozitsionnoy regulyatsii sotsial'nogo povedeniya lichnosti. Metodologicheskie problemy sotsial'noy psikhologii, sb. st. (M., 1975)

15. M.D. Hills, Kluckhohn and Strodtbeck's Values Orientation Theory (2002) https://scholarworks.gvsu.edu/orpc/vo14/iss $4 / 3$

16. O. Khokhlina, L. Pomytkina, O. Lych, S. Gorbenko, A. Kazak, IOP Conf. Series: Materials Science and Engineering 918, 012175 (2020) doi:10.1088/1757899X/918/1/012175

17. S.H. Schwartz, V. Ros, Value priorities in West European nations: A crosscultural perspective, Studies in psychology: A volume in honor of Sonny Kugelmas. Scripta Hierosolymintana (Jerusalem, 1994)

18. S.H. Schwartz, Advances in Experimental Social Psychology 25 (1992) https://dx.doi.org/10.1016/S0065-2601(08)60281-6 